\title{
GENDER ISSUES IN TEACHING METHODS: REFLECTIONS ON SHIFTING THE PARADIGM ${ }^{\dagger}$
}

\author{
MARY JANE MOSSMAN*
}

\section{INTRODUCTION: THINKING ABOUT GENDER AND TEACHING METHODS}

If education is to play a major role in bringing about the changes for which we are looking, then we need new ways of envisioning the possibilities for teaching and learning ...

What are the possibilities for feminist practices within the academy that will not send our words to hide behind a wall of silence washed by pain? ${ }^{2}$

Magda Lewis' words capture for me the paradox of "possibilities" and "pain” in my law school classrooms. As she has suggested, the university context presents possibilities for feminist teaching strategies that enliven the classroom with their "liberating potential". Yet, in the face of cavalier attitudes towards the project of bringing women's experiences "out of the shadows”, classrooms may also be hostile places for feminist law teachers. ${ }^{3}$ And often, this experience of "possibility" and "pain" for a feminist academic occurs not as two separate states, but as a subtle interweaving, a fusion of hope and despair:

The academy provides a potentially privileged space from which women might speak. What we do with this privilege is the challenge of any revolutionary project including that of feminism... The liberating potential of community, vision, hope, and laughter (of which there is a great deal) are the positive moments of our collective struggle ... [Yet], we [also] reach out for support from one another in those moments of despair and disillusion when we are faced with that student who has come for the easy mark (for what else could a course in feminist theory, feminist research or women's studies, taught by a woman, be?) ... The word "easy" also carries a double social meaning that would be, by and large, irrelevant were we men, but has deeply violating implications in the lives of women. ${ }^{4}$

This paper focuses on gender issues in teaching methods as one part of feminism's larger project of revisioning legal education to bring women's experiences “out of the shadows". 5 To take account of gender issues in teaching methods requires us to focus on gender in our relationships within the academy and within our classrooms, and to understand ourselves and others as "gendered subjects" in relationships of teaching and learning. In this way a focus on gender issues in teaching methods in legal education requires an exploration of why such teaching creates both "possibilities" and "pain". The first part of this paper situates these issues in the context of struggles between traditional approaches and feminist challenges to law, and the consequences of these struggles for feminist law teachers. In relation to these struggles, the paper then explores parallel debates about pedagogy in terms of more traditional approaches and feminist challenges to them. This analysis shows connections between traditional ideas about law and about pedagogy on one hand, and connections between feminist challenges to law and to pedagogy on the other. It also reveals interesting patterns in traditional claims to objectivity that occur in both law and pedagogy, and feminist challenges which demonstrate the "hidden" ${ }^{6}$ gender in these claims in both contexts. My interest in the contrast between traditional and feminist approaches to both law and pedagogy results from an increasing dilemma about my classroom teaching: as the content of my courses becomes more critical, especially feminist, my teaching methods seem to be ever more traditional. From my perspective, my classrooms seem to require me to exercise authority rather than foster consensus, and they are much too large to permit many students to participate effectively in classroom discussion. Although I have no doubt that (some) women students may need to learn differently from (some of) their male colleagues, I have not generally adopted feminist pedagogical approaches in my law classes. My approach reflects a concern that 
using both feminist content and feminist pedagogy would probably invoke law's power to make feminist law teachers "fringe dwellers in the jurisprudential community". ${ }^{7}$ Yet from the perspective of pedagogy my approach also reflects the complexity of efforts to teach all the students in my large classes (students who are an increasingly diverse group of people with differing needs), and to teach all of them effectively Such a goal regularly offers not only "possibilities" but also "pain". Beyond both traditional and feminist approaches to teaching in law schools, the paper suggests that feminist law teachers may need to approach issues of gender and teaching methods in terms of a paradigm shift, to take account of how both students and teachers are gendered subjects in the same classroom. As a group of feminist educators has explained:

Our very presence within the academy as "woman thinking", or the female authority, alters the fundamental construction of gender in our culture ... For our students, for ourselves, and for our superiors, we are not clearly "us" or "them". The facts of class, of race, of ethnicity, of sexual preference - as well as gender -may cut across the neat division of teacher/student ...8

Being a gendered subject in relation to my students, who are themselves also gendered subjects, makes the issue of teaching methods much more complex: more complex than traditional approaches to law teaching, which assume that most teachers and most of their students (or at least the ones that matter) are male; and also more complex than some feminist approaches, which often assume that the teacher and most of the students (or at least the ones that matter) are women. By recognizing teachers and students as gendered subjects, we must take account of differences among women and among men who are teachers and students, and how these differences may resist — or reinforce — power relations both inside and outside the classroom. Understanding the experience of "possibilities" and "pain" as part of a paradigm shift in approaches to law teaching may thus offer ways of rethinking teaching methods in the context of the diversity of law schools and the legal profession. ${ }^{9}$

\section{THE CONTEXT OF LAW AND LEGAL EDUCATION: “POSSIBILITY” AND “PAIN” IN FEMINIST CHALLENGES TO THE STATUS QUO}

.Imagine a sandbox and there sit the boys with their tools and they say to the girls maybe you could come and help me make some facts and if you are nice you can use some of my tools. And if you are really nice and I am in a real hurry and have to make a lot of facts for a lot of people, I can show you how to use those tools ... The conflict arises when the girls say "Really you know, we want to use our own tools, maybe we want to make our own facts. Maybe we even want to have our own sandbox.” ... [The] challenge of feminist scholarship ... is the struggle for the sandbox and the tools. ${ }^{10}$

Ursula Franklin's characterization of feminism in the academy as "the struggle for the sandbox and the tools" aptly describes the tension between traditional approaches to law and competing feminist challenges. Law's traditional claims to neutrality and objectivity, and its capacity to draw boundaries so as to exclude all but "relevant" issues for legal consideration, ${ }^{11}$ have been criticized, both because they mask and conceal "hidden" biases and also because they reflect, in fact, only a partial (male) viewpoint. ${ }^{12}$ Traditional approaches to law developed at a time when there were either no women members of the legal profession and the judiciary, or very few, ${ }^{13}$ when most women were not legal subjects at all, when they could not vote as citizens, and when their opportunities for paid work were narrowly confined. ${ }^{14}$ In this way law's traditional approaches to issues like citizenship, work and violence (issues which are important to feminism's curricular reform project), were developed at a time when the legal profession was exclusively (or almost exclusively) male.

In this context of (white, able-bodied, Anglo, heterosexual) male exclusivity in the legal profession and law's claims to neutrality and objectivity, the dominant teaching method in law schools (lectures to large numbers of students) reflected both an unproblematic view of the idea of "knowledge" and an acceptance of the idea of "teaching" as merely the efficient transfer of information: the "banking system of education". As bell hooks has described her experience with this system of education:

In graduate school I found that I was often bored in classes. The banking system of education (based on the assumption that memorizing information and regurgitating it represented gaining knowledge that could be deposited, stored and used at a later date) did not interest me. I wanted to become a critical thinker. Yet that longing was often seen as a threat to authority. ${ }^{15}$

In spite of criticism by students like hooks, much of the traditional literature on pedagogy has accepted 
the usefulness of the "banking" or "transfer" approach to education, emphasizing elements of good organization and clear communication to achieve an efficient and effective transfer of information. In principle, moreover, there was little space to challenge this approach and efforts to do so were often seen, as hooks has noted, as "a threat to [the teacher's] authority".

Traditional approaches to pedagogy also did not acknowledge differences among students (including differences on the basis of gender). In his assessment of both traditional and more challenging theories about teaching, Dennis Fox identified four different approaches: the "transfer" theory, the "shaping" theory, the "travelling" theory and the "growing" theory, all of which were reflected in teachers' answers to the question "What do you mean by teaching?" As he explained these different theories:

[With] the transfer theory of teaching, ... the subject material is viewed as a commodity to be transferred to the students' minds ... Whilst the transfer theory views the student as a container or vessel to be filled, the shaping theory views the students as clay or wood or metal to be shaped or moulded into a predetermined form ... From the viewpoint of the travelling theory, the process of teaching is like helping students on a journey through unfamiliar and often tough terrain. The growing theory on the other hand views teaching as being a matter of encouraging and helping students in their personal growth and development - rather like an expert gardener encourages the growth of plants in the various parts of a productive garden. ${ }^{16}$

According to Fox, "the lecture is the classical manifestation of the transfer theory in action", ${ }^{17}$ although it may also be used by teachers who subscribe to the shaping theory because it offers a splendid opportunity for "[demonstrating authority] through the sheer force of the spoken word and the authoritative presence of the expert on this controlled, passive raw material" ${ }^{18}$ Both transfer theories and shaping theories, moreover, assume that "teaching is a fairly simple matter of arranging the transfer or the shaping". ${ }^{19}$ In the legal education context, transfer or shaping theories thus reflect and reinforce traditional ideas about law: by assuming that law can be taught using "unproblematic" processes of transferring or shaping "unproblematic" ideas about law, neutral law teachers "teach" students undifferentiated by gender or any other factors.

Moreover, so long as most law teachers were male and most law students were male (and so long as there was very little other diversity in the population of law schools or in the legal profession), the "transfer" method of law teaching could plausibly claim at least some effectiveness as a means of accomplishing these "unproblematic" legal education objectives. By contrast, other approaches to teaching assume more involvement by students and tend to characterize teaching in terms of the "learning environment”. Both Fox's travelling theory and growing theory start from these kinds of assumptions:

[that] ... the student is a fellow traveller with individual and valuable experiences and abilities, motives and objectives, many of which might be rather ill-defined and disorganized and some of them less useful than others. The teacher's job is to use his (sic) own experience and expertise to help the students to get their own ideas in order so that they can make more sense of their experience and of what lies ahead still to be mastered. ${ }^{20}$

Clearly, travelling and growing theories about teaching, by contrast to transfer and shaping theories, challenge to some extent the idea of objective "knowledge". At the same time, however, they do not seriously question how differences (including gender differences) among students may affect experiences, abilities, motives or objectives, ${ }^{21}$ or how gender may affect relationships of teaching and learning in ways which are themselves problematic.

Theories of teaching in terms of travelling and growing are developed in a more critical context in Paulo Freire's "teaching for liberation" theory, now a fundamental theory for critical pedagogy, ${ }^{22}$ even though Freire's work also failed to take account (at least initially) of the impact of gender. ${ }^{23}$

As is obvious, therefore, there are some important connections between traditional approaches to law and to pedagogy, and the critical responses to each of them. Traditional approaches to both law and pedagogy assume their own "neutrality" and objectivity, and neither of them makes the idea of "knowledge" problematic in terms of its partiality or the perspective of the "knower". Moreover, the dominant form of educational method in law, lectures to large groups of students, is entirely consistent with a concept of law as simply information which can be transferred. ${ }^{24}$ Even the metaphor of the "banking system of teaching" seems particularly apt to describe traditional approaches to legal education! At the same time, there are also parallels in more critical perspectives in both law and pedagogy. Critical perspectives on law challenge ideas about its neutrality just as critical pedagogy challenges the neutrality of "knowledge" and of "knowers". Perhaps more significantly, there is some unease in both law and pedagogy 
about the challenges posed by critical legal analyses and critical pedagogies. ${ }^{25}$ And, although they have occurred alongside critical responses (like Freire's) to traditional approaches to law and pedagogy, feminist legal analyses and feminist pedagogies remain somewhat distinct, offering critiques to traditional and to critical approaches on the basis that they have both failed to take gender into account.

For example, feminist analyses of law ${ }^{26}$ challenge assumptions about law's neutrality and objectivity by demonstrating the partiality of gendered (male) experiences masked in apparently neutral legal principles. Feminist analyses also critique law's claims that women are equal legal subjects by showing how interests which are important to (some) women may remain invisible to legal categories and thus without redress in terms of legal remedies. ${ }^{27}$ In this context, feminist analyses try to "reframe" existing categories or invent new ones which appropriately reflect diversity among women and which advance their position as equal legal subjects with men.

Feminist pedagogies similarly direct attention to new "knowledge" about the ways that the learning context may itself be gendered, and challenge claims about inherent values so as to reveal hidden, gendered (male) perspectives. For example, Nancy Schniedewind has identified several features of feminist pedagogies in the context of women's studies: ${ }^{28}$ development of an atmosphere of mutual respect, trust and community in the classroom $;^{29}$ shared leadership ${ }^{30}$ cooperative structures; ${ }^{31}$ integration of cognitive and affective learning, ${ }^{32}$ and action to transform institutions and values. ${ }^{33}$ Some feminist scholars have identified aspects of feminist pedagogies in legal education; ${ }^{34}$ consciousness-raising, ${ }^{35}$ destruction of artificial barriers, rejection of abstraction, and perpetual questioning ${ }^{36}$ while others have supported similar pedagogical approaches on the basis that women's ways of learning are enhanced by these and other strategies of feminist pedagogy, a claim which suggests that women and men do not all learn in the same ways. ${ }^{37}$ In this way, feminist pedagogies, like feminist legal analyses, represent challenges to the status quo in legal education, challenges which have been increasingly documented in relation to curricula ${ }^{38}$ and environmental ${ }^{39}$ concerns, as well as pedagogical ones.

Yet, in the context of feminist challenges to traditional approaches to law and pedagogy, there are two problems which must be confronted. One is that when feminist analyses and feminist pedagogy confront more traditional approaches to law and legal education, they do so on the basis of law's traditional claim to "Truth" ${ }^{40}$ In a somewhat different context (that of searching for new legal concepts more responsive to the complexity of women's experiences of battering by their male partners), Christine Littleton labelled this challenge "the problem of transition". According to Littleton, a problem of transition occurs when an existing system of power is confronted by non-conforming patterns of behaviour. In such a context, Littleton suggested that the non-conforming patterns of behaviour appear deviant, and that they result in particular kinds of consequences for those involved in such challenges:

By defining the "terms of the debate", or the range of acceptable discourse, it [the existing system of power] makes challenges that start from non-conformist premises appear not only deviant, but often literally incomprehensible, and by defining the reward system, it makes nonconformist action expensive in both tangible and intangible ways. ${ }^{41}$

In the current legal education context, feminist challenges to law's traditional claims about its neutrality and objectivity may, as Littleton has suggested, appear deviant, even incomprehensible. Such challenges may also be risky for teachers and students who advance them. ${ }^{42}$ In this way, feminist pedagogies, like feminist curricular challenges, struggle against traditional ideas about law as "Truth, and with no guarantee that there will be a "paradigm shift" or "transition" in this power relationship.

In practice, this means that there may be some specialized seminars in the law school context, involving teachers and students with an interest in feminist analyses, that may usefully adopt feminist pedagogies: non-hierarchical arrangements for classroom discussions, the use of consciousness-raising and personal disclosure, cooperative rather than competitive learning techniques, etc. Even so, such seminars (both in terms of content and process) may be regarded by others as profoundly deviant in relation to traditional legal education methods used in other courses and seminars: hierarchy and authority in the classroom, abstract and "neutral" reasoning about cases and clients, and the relentless competitiveness fostered by classroom environments and evaluation methods. In this way, the adaptation of feminist pedagogies from other university contexts (especially women's studies) to the legal education context may frequently appear deviant, even incomprehensible, in relation to law's "existing system of power". This conclusion does not mean that feminist law teachers should not use feminist teaching methods, but it does explain why their 
experiences of frustration and difficulty in law school classrooms may be particularly acute.

Law's power also requires an examination of a second problem: the relationships of students among themselves and with their teachers, both inside and outside classrooms, and the gendered (and other) power relationships inherent in law teaching. Although law's power has frequently been addressed by feminist analyses, its impact on classroom dynamics requires a closer examination of the relationships of power among students and teachers as gendered subjects. Such an examination shows the limits of both traditional and feminist pedagogies in the law school context, especially in law school classrooms with large numbers of students and their diverse expectations: traditional pedagogies may not address issues of power at the heart of law's claims to neutrality, while feminist pedagogies that challenge law's power to claim "Truth" may be rendered deviant and even incomprehensible.

In such a context, teaching methods must take account of classroom participants as gendered subjects, acknowledging the web of power relationships in teacher/student and student/ student relationships, as well as the ways that gender issues are hidden within law's claims to objectivity and neutrality. Thus, building on the insights of traditional and feminist pedagogies, the idea of teachers and students as gendered subjects in law school classrooms may be helpful in shifting the paradigm of law teaching so as to take account of gender issues beyond "the fringes of the jurisprudential community". ${ }^{43}$

\section{TEACHERS AND STUDENTS AS GENDERED SUBJECTS: A PARADIGM ... SHIFTING?}

... For some reason my classes are never like those described. The longer I teach them, the less homogeneous they seem. I am working out my role as a woman's studies teacher in a university in which — as in most others, I suspect - no class consists of just working-class women, just reentry women, just Native American women. It is time to discuss the work of the feminist teacher in a mixed classroom, where any constituent group may be a minority and the smallest consistent minority group is feminist students. ${ }^{44}$

Both the diversity of experiences and power among students in law school classrooms and the law's power to resist challenges to its inherent neutrality make it difficult to adapt feminist pedagogies from a women's studies context to legal education. Although feminist pedagogies may work well among teachers and students in a context of shared expectations about processes and objectives (such as often exist in women's studies courses and some specialised seminars in law schools), they may be less useful in larger, more diverse groups of students. Indeed, as is suggested in the comment above, even women's studies teachers have identified some difficulties in teaching "the feminist minority" within settings where most students are women. Thus, focusing on the idea of teachers and students in gendered (and other) relationships of power, especially in large and diverse (mixed) classrooms, permits us to examine the problem more effectively and to define what strategic choices are available. ${ }^{45}$

At the outset, it is important to explore the impact of gender in defining the relationships among teachers and students. As others have suggested, for example, a woman teacher in a university setting is likely to be perceived as less authoritative than a man in the same context: as a different and gendered subject. Susan Stanford Friedman explained this phenomenon as one of "gendered authority:

A man stepping into the role of professor has a certain authority granted to him by his students that operates immediately. Women, on the other hand, must earn that authority and respect, which is in any event often granted with great resentment, even hostility. Some women become "100 per centers" to achieve authority, often taking pride in being tougher and less personal than many male colleagues. And ... students may pressure any woman teacher to fulfil the role of the all-forgiving, nurturing mother whose approval is unconditional. Thus, the clashes at grading time. Thus, the hostile challenge to her authority to know that many women have faced. ${ }^{46}$

A woman teacher who combines the role of intellectual with that of nurturer challenges traditional and gendered patterns of behaviour, sometimes in unexpected ways. In her research about patterns of interaction in university classrooms, Paula Treichler found that women teachers generated more classroom discussion and interaction, encouraging more give-and-take among students. In direct relation to the extent that an individual woman teacher does so, however, Treichler noted that "students evaluate her classes as friendlier, livelier, less authoritarian, and more conducive to learning". Yet, at the same time, they also judge the woman teacher to be less competent! Thus, as Treichler concluded, "behaviour judged as traditionally male — a lecture format, little student give-and-take, the transmission of a given body of content, little attention 
to process — seem also to signal professional competence." ${ }^{47}$ Similarly, Susan Heald has reported that her student evaluations showed that students who responded positively to her course did not link their positive experience to her feminist pedagogy, while those who did not like the course expressed the view that her feminist bias was too strong. ${ }^{48}$ For the woman who is a law teacher, moreover, her position of authority in the classroom is gendered, not only in terms of the traditions of the university setting but also because of those of the legal profession. Her role thus challenges the traditional paradigms of both university teaching and of law.

In addition to the gendered roles of professors, moreover, a large and diverse law class means that students will also occupy different and gendered roles. Some recent American research has demonstrated, for example, that the gender of both the teacher and the students makes a difference to the results of teaching evaluations. As Susan Basow has reported:

Research documents that people who violate expectations generally are rated more negatively than people who behave as expected. To receive good evaluations, male professors simply must demonstrate their competence and knowledge; that is, they need to fulfil their stereotypical gender role expectations. But female professors bear a double burden: they must fulfil both their gender role by being nurturant and warm, as well as their professional role by being competent and knowledgeable. ${ }^{49}$

Basow also reported that women professors were judged more negatively than male professors if women professors were not more available to students than male professors. Yet, even when female professors were more available than their male colleagues, female professors' ratings were no higher than male professors'. As a result, Basow concluded that "in order to receive comparable ratings, female professors need to do more than their male counterparts.” More significantly findings that show no difference between male and female professors may completely mask the fact that students are applying different standards in their evaluations. ${ }^{50}$

Basow also reported that male students (especially) tended to rate female faculty more poorly than male faculty. Speculating on why this differential existed, she suggested:

Research documents that men, compared to women, hold more traditional attitudes toward gender roles and demonstrate more bias against gender-role violators... [Males] majoring in business and economics or in engineering rated female faculty most negatively. We found that those students have the most traditional attitudes toward women and gender roles. ${ }^{51}$

Although law students were not included in Basow's categories of male students most likely to have traditional expectations about their teachers, it is likely that some law students' perceptions would be similar to those in her report. Thus, a feminist law teacher may be most effective in teaching students with traditional expectations (perhaps more often male students) by adopting teaching methods which emphasize traditional competence and authority in the classroom.

Yet, such an approach may have detrimental consequences for other students in the same classroom. For example, women students who are feminists are likely to have competing, different gendered expectations. A critique by a Canadian feminist law student, for example, expressed disappointment in her female law teachers "for not trying to make changes in legal education" and for "acting in obviously sexist ways". 52 Indeed, high expectations about the role of feminist law teachers on the part of feminist law students means that student expectations may not always be met satisfactorily, especially in mixed classrooms. The feminist law teacher's dilemma of different and incompatible student expectations was expressed poignantly by Carol Neely, a professor of literature:

... I find myself having to decide daily whether it is ideologically or pedagogically appropriate or psychologically possible to present myself as oppressed victim, as ruthless achiever, as nurturing mother, as superwoman, or whether it is better to reveal the hidden and disintegrated self beneath the roles — feminist critic as hysteric, perhaps — the madwoman out of the attic and expected to function sanely in the world. ${ }^{53}$

Neely's description of conflicting roles aptly describes the dilemma experienced by some feminist law teachers in large and diverse classrooms, where some students have traditional expectations and others more feminist ones, and where there are also other differences among students which affect their relative access to power in the classroom. ${ }^{54}$ Recognizing the power of traditional ideas about law and pedagogy as well as feminist challenges to both, and taking account of expectations created for herself and her students as 
gendered subjects, the feminist law teacher may well experience Neely's reality as "madwoman".

At the same time, however, a recognition of herself and her students as gendered subjects offers a starting point for teaching methods that expressly take into account that all students are not equal in terms of power, and that gender is one important variable in power relationships both in law school classrooms and beyond. ${ }^{55}$ As Frances Maher has argued, such an approach permits us to see the connections between our classrooms and society:

We want to educate women (and men) to a realization of the full worth and legitimacy of their own experience, as well as that of others. But can we really imagine a society that takes female voices as seriously as male voices, black voices as seriously as white ones, working-class voices as seriously as managerial ones? Inside the classroom we can dismantle, disperse and democratize the powers of knowledge and the means of acquiring it. However, we also need to examine explicitly the dimensions of the society our students will enter. ${ }^{56}$

The power relationships concerning gender and other dynamics in mixed classrooms are complex not only because of power relationships beyond the university, but also because of the need to (re)discover ways of communicating across difference in the process of teaching and learning. Uma Narayan has explored in some detail the nature of relationships in discussions where participants include both those who are advantaged and those who are disadvantaged, a situation which is "characterized by the presence of historically constituted relations of power, privilege and lack of understanding". ${ }^{57}$ She has suggested, for example, that members of oppressed groups may be better able to describe the experience of their oppression, "the ways in which the oppression affects the major and minor details of their social and psychic lives, ... the detailed and concrete ways in which oppression defines the spaces in which they live..." ${ }^{58}$ However, this conclusion does not mean that people who are not members of the oppressed group can never understand these experiences or acquire insights or knowledge about disadvantage:

Such a claim would have very undesirable consequences. It could be taken as a license to excuse all those who are not members of any oppressed group from any concern with that oppression. After all, if they can never understand many or most significant aspects of that oppression, how could they meaningfully take an interest in it or help fight against it?...59

As Narayan has suggested, however, communicating across difference depends on understanding the power dynamics of such a process, not just relying on goodwill to "take care of all such problems". ${ }^{60}$ In the context of gender and race issues, moreover, Elizabeth Ellsworth has documented how even ideas about "empowerment", "student voice" and "dialogue" may operate as repressive myths within a university setting that contains hidden power relationships. Her suggestions for teaching methods that take account of this hidden power within relationships of gender and race emphasize the importance of seeking understanding and commonality among experiences without compromising distinctive realities:

Right now, the classroom practice that seems most capable of accomplishing this is one that facilitates a kind of communication across differences that is best represented by this statement: "If you can talk to me in ways that show you understand that your knowledge of me, the world, and "the Right thing to do "will always be partial, interested, and potentially oppressive to others, and if I can do the same, then we can work together on shaping and reshaping alliances for constructing circumstances in which students of difference can thrive”. ${ }^{61}$

These insights are helpful in understanding the challenges for feminist law teachers in large and diverse classrooms where the gendered subjectivity of the teacher and the students may, along with other differences, affect both teaching and learning. And, because law school classrooms are much more often mixed classrooms rather than "feminist" classrooms, the project of designing teaching methods with an understanding of how gender (for both the teacher and the students) may affect their interactions is critically important. For me, this project is one which builds on feminist analyses in both law and pedagogy but which turns its focus to the "typical" law school classroom, a place where it is increasingly important to find ways to communicate effectively across all of our differences. ${ }^{62}$

Yet, the power of law's claim to "Truth" means that law school classrooms will continue for some time as sites of both "possibilities" and "pain" for feminist law teachers. Feminist approaches to teaching methods provide new possibilities for teaching and learning effectively, particularly for women and feminist students. Yet, especially in large, diverse classes, teaching methods (including feminist pedagogies) that challenge traditional approaches may also continue to be marginalized as deviant, even incomprehensible. Shifting the paradigm in law teaching thus requires us to confront gender issues in relation to law's power, not only in teaching methods but also in our relationships in the classroom. For me, 
this conclusion means that my classroom will continue to be a place for "envisioning the possibilities for teaching and learning", and yet also one where my words will sometimes disappear "behind a wall of silence washed by pain”.

Understanding the classroom as a place where these paradoxical ideas are fused in hope and despair acknowledges both the strength of the status quo and also the opportunities for resistance: the potential for shifting the paradigm. By being conscious of the existence of gendered and other kinds of power relationships in the classroom, there is some opportunity for feminist law teachers to challenge students to re-think their assumptions, to re-create a learning environment together that takes differing student needs into account, and to re-vision law and legal processes for our diverse communities. At the very least, by paying attention to gender issues in teaching methods, we may be able to construct teaching methods more appropriate to our objectives and our students in different kinds of teaching contexts. At this point, as we experience the "possibilities" and the "pain" of a paradigm shift, moreover, we need to record and to share our experiences and insights. In accepting this challenge in law school classrooms, Ursula Franklin's advice to a graduate student may be equally apt for feminist law academics:

And finally when the going is tough and you feel yourself surrounded by jerks, take an anthropological approach. Take field notes (and I mean this in real and practical terms) and regard yourself as an explorer, having come upon a strange tribe. Observe and describe the tribe's customs and attitudes with a keen detachment and consider publishing your observations. It may help you and be of use to future travellers. I know from experience that the exercise works. $^{63}$

$\dagger$ This paper was originally presented at the Feminist Legal Academics’ Workshop in Canberra in February 1995, and the comments and ideas of participants at the Workshop are warmly acknowledged. I also acknowledge the assistance of Hazel Pollack at Osgoode Hall Law School and the support of my colleagues at the Human Rights Research and Education Centre at the University of Ottawa.

* Osgoode Hall Law School, York University. (C) 1996 (1995) 6 Legal Educ Rev 129.

1 MG Lewis, Without a Word: Teaching Beyond Women's Silence (New York: Routledge, 1993) 43.

2 Id at 146.

3 Id at 149.

4 Id at 146-48. The combination of "possibilities" and "pain” reflects the problems of teaching in the academy for many people, not only feminists and not only law teachers. For feminist law teachers, however, there may also be the problem of violence. As Teresa Scassa has suggested: "While the presence of women in professional faculties is celebrated as a sign of tolerance and equality in our society, the reality for these women is less equal and much less tolerant. Their presence is a daily challenge to male dominance. It is a challenge which is sometimes met by violence.” (T Scassa, Violence Against Women in Law Schools (1992) 30 Alta L Rev 809, at 811.) See also C Boyle, Teaching Law as if Women Really Mattered, or, What about the Washrooms? (1986) 2 Can $J$ Women \& L 96, at 109-11; and M Culley \& C Portuges eds, Gendered Subjects: The Dynamics of Feminist Teaching (Boston: Routledge and Kegan Paul, 1985).

5 Such a project must focus on reforming the curriculum as well as teaching methods, always taking account of the close relationship between them. Yet, the revisioning of teaching methods may present the more daunting project. Since law is dependent on "facts", a curricular reform project which focuses on gender and which shows that there are some important facts "missing", may influence changes in the content and structure of law school courses. For example, see M Eberts, New Facts for Old: Observations on the Judicial Process, in R Devlin ed, Feminist Legal Theory (Toronto: Emond Montgomery Press, 1991) 110. Unlike much curricular reform, however, the reform of teaching methods requires law teachers to focus inward — on the academy and on themselves. That is, while curricular change may require law teachers to focus on gender issues as manifested in courts and in legislatures and other decision-making tribunals, all of them are comfortably outside the academy. By contrast, teaching methods which take gender into account challenge teachers and students in the classroom, within the academy itself.

6 The idea of "hidden" gender in law was explored systematically in R Graycar \& J Morgan, The Hidden Gender of Law (Sydney: Federation Press, 1990).

7 M Thornton, Dissonance and Distrust: Women and the Legal Profession (Melbourne: Oxford University Press, 1996).

8 M Culley et al, The Politics of Nurturance, in Culley \& Portuges eds, supra note 4, at 11 and 13.

9 This paper has provided an opportunity to rethink feminism's "transformative project" in relation to issues about gender and teaching methods, by contrast with curricular change. In relation to the latter, see M Mossman, "Otherness" and the Law School: A Comment on Teaching Gender Equality (1985) 1 Can J Women \& L 213. See also, Can. Assoc. of Law Teachers, Equality in Legal Education (1992) 17 Queen's LJ 174.

10 U Franklin, The Sandbox and the Tools, in J Leith et a1 eds, Transactions of the Royal Society of Canada (Toronto: University of Toronto Press, 1990) 43.

11 See M Mossman, Feminism and Legal Method: The Difference it Makes (1986) 3 Austl J L \& Soc'y 30.

12 The idea of the law's "point of viewlessness" as inherently male was most clearly articulated in C MacKinnon, Feminism, Marxism, Method and the State: Toward Feminist Jurisprudence (1983) 8 Signs 635, at 638-39: "[M]ale dominance is perhaps the most pervasive and tenacious system of power in history, ... it is metaphysically nearly perfect. Its point of view is the standard for point-of-viewlessness, its particularity the meaning of universality." For a more recent analysis of law as "sexist", "male" or "gendered", see C Smart, The Woman in Legal Discourse (Utrecht: University of Utrecht, 1991).

13 For an analysis of the relation between women's legal claims and the role of women in the legal profession, see M Mossman, The Paradox of Feminist Engagement with Law, in N Mandell ed, Feminist Issues: Race, Class and Sexuality (Scarborough: Prentice Hall, 1994); and M Mossman, "Invisible" Constraints on Lawyering and Leadership: The Case of Women Lawyers (1988) 20 Ottawa L Rev 567. 
14 The status of women as legal subjects continues to be deeply ambivalent, particularly for some women, such as First Nations Women in Canada. Although they achieved the right to vote a few decades ago, those who live on reserves are not entitled to the protection of family law statutes governing matrimonial property, in spite of serious problems of violence in their homes. See ME Turpel, Home/Land (1991) 10 Can J Fam L 17.

15 b hooks, Teaching to Transgress: Education as the Practice of Freedom (New York: Routledge, 1994) 5. See also Fox, infra for further analysis of the "banking” system of education.

16 D Fox, Personal Theories of Teaching (1983) 8 Stud Higher Educ 151, at 151-152. The "transfer theory” here is similar to hooks' "banking theory".

17 Fox illustrates this point by the jokes made about lectures: "the old adage about the lecture being an occasion when the notes of the lecturer become the notes of the students without passing through the minds of either illustrates the transfer theory operating rather like a large photo-copying process". He also suggests two variants on the transfer theory: the "baby food manufacturing analogy" in which "the teacher sees his (sic) job as one of processing very tough material into more easily digestible nutrient for rather simple minds"; and the "broadcast theory" which "views teaching as scattering seeds to the wind rather than transferring them to specific containers”. According to this latter variant, Fox suggests (at 153) that the obligation of a teacher is only to: “... deliver himself (sic) of his nuggets of wisdom. Whether or not these are relevant or applicable in particular contexts or whether they make any sort of sense to anybody but himself (sic) is not his (sic) concern. His (sic) responsibility is solely concerned with ensuring the purity of the seed."

18 Id at 154. According to Fox, transfer and shaping theories in subjects like mathematics and law use practical exercises or problems. "The usual teaching strategy ... is for the teacher to demonstrate the way of solving the problem by "going through it" at the blackboard or overhead projector and then for students to be required to solve similar problems by the same methods."

19 Id at 156 .

20 Id.

21 Fox does note the possibility of "mismatches" between teachers and students, but not among students. Thus, where a teacher uses shaping or transfer theories while a student wishes to be taught by travelling or growth theories, or vice versa, a mismatch is likely to occur. Id at 160 .

22 The relationship between critical pedagogy and feminist pedagogy is explored in C Luke \& J Gore eds, Feminisms and Critical Pedagogy (New York: Routledge, 1992). According to the editors, the authors of these essays arrived at their viewpoints on critical pedagogy from their "positioning, location, and identity as women in education: as women within a patriarchal system of knowledge, scholarship, and pedagogical relations". Id at 3.

23 bell hooks has directly addressed concerns expressed by feminists about Freire's failure to take gender into account, stating firmly that "I want to say that I felt myself included in Pedagogy of the Oppressed, one of the first Freire books I read, in a way that I never felt myself - in my experience as a rural black person — included in the first feminist books I read, works like The Feminine Mystique and Born Female, hooks, supra note 15, at 51 and chapter 4.

24 See also J Macfarlane, Look Before you Leap: Knowledge and Learning in Legal Skills Education (1992) $19 \mathrm{~J} L$ \& Soc'y 293, at 299: "The assumptions of an objectivist epistemology appear to be built into most manifestations of legal education, and are sometimes so well entrenched that we forget to question them."

25 See Luke, \& Gore, supra note 22; and also K Weiler, Women Teaching for Change: Gender, Class and Power (South Hadley, Mass: Bergin and Garvey Pub. Inc., 1988) 71, who linked feminist approaches and those of Freire: "Feminism calls into question existing definitions of reality ... and forces people to interrogate their own common sense view of the world... At the same time, feminism is committed to social transformation. Changing people's consciousness is not enough; real relationships and forms of power must be changed.” As Freire points out, it is not enough for the oppressed to recognize their own oppression. That recognition is only the starting point for a movement to destroy that oppression and to become free in fact and not simply in the mind.

26 For an overview, see Graycar, \& Morgan, supra note 6.

27 There are important critiques of the partiality of feminist perspectives Rom women whose perspectives differ from those articulated by white, middle-class, heterosexual women. See N Mandell ed, Feminist Issues: Race, Class and Sexuality (Scarborough: Prentice Hall, 1994).

28 N Schniedewind, Feminist Values: Guidelines for Teaching Methodology in Women's Studies, in C Bunch, \& S Pollack eds, Learning Our Way: Essays in Feminist Education (Trumansburg, NY: The Crossing Press, 1983) 261.

29 As concrete examples, Schniedewind suggests activities such as: students pairing with someone they don't know (at the beginning of the course) to discuss a woman role model; "I-messages" (statements of critical feedback given to one another in a supportive way); democratic processes for discussion and leadership; and "festive" times, including the use of songs or poetry in the course of potluck dinners. Id at 262-63. Some of these approaches may also be used by critical as well as feminist teachers, but they are generally absent from traditional approaches to teaching.

Evelyn Torton Beck, another feminist teacher, has also considered the issue of "self-disclosure" in the context of feminis pedagogy. According to responses to a survey conducted among her students, most students believed self-disclosure by the teacher was a positive attribute in the classroom because it "encouraged openness in students, created a good atmosphere, brought unity to the group, validated diversity, and altogether made the class more meaningful.. ." See Self-Disclosure and the Commitment to Social Change, in Bunch, \& Pollack eds, supra note 28, 285, at 287. Such a stance, of course, is quite inconsistent with the idea of complete neutrality on the part of the teacher epitomised by the "banking theory" of teaching and traditional approaches to law.

30 Schniedewind offers several examples, some of which may also occur in classrooms where there is less hierarchy and more sharing of responsibility, even if the classrooms are not feminist: feedback and evaluation during a course, sharing the results with students, and discussing how to resolve problems. Schniedewind, supra note 28, at 264-66.

31 Suggested methods include collaborative discussion of questions by small groups in the classroom, pass/fail grading or contract grading (setting out in advance the criteria for achieving an A, B or C grade, indicating both the type and quality of work required), etc. Id at 266-68. Some of these methods may also be adopted in classrooms which promote cooperative work rather than merely individual initiatives on the part of students.

32 Suggestions include the use of journals, the integration of experiential activities, and questions which require students to make connections between readings and their personal lives. As the author suggests (Id at 268-69): "Feminism values both intellectual and emotional capabilities. Feminists struggle to change the overly rational premises of male-dominated social relations and institutions, and to incorporate priorities appreciative of human needs and feelings... Our teaching can synthesize both the cognitive and affective areas of human learning.” See also C Gilligan, In a Different Voice (Cambridge, Mass: Harvard University Press, 1982). 
33 Schniedewind requires students to undertake field-based action in order to receive an A grade. She acknowledges that such an approach is difficult to achieve but nonetheless essential to a feminist approach to teaching and learning: "As long as we live in a sexist society, feminism inevitably implies taking action to transform institutions and values. Perhaps the greatest threat to feminism in the university is the ease with which we can allow the curriculum to reflect thought without action.” (Schniedewind, supra note 28 , at 270.)

34 M Torrey, J Casey, \& K Olson, Teaching Law in a Feminist Manner: A Commentary from Experience (1990) 13 Harv Women's LJ 87. The article reports on a seminar on feminist jurisprudence composed of 10 students, nine of whom were women. The article was authored by the professor and two students.

35 According to the authors (Id), "consciousness-raising gives women and other silenced minorities a voice”. Perhaps because of the small size of the group of students, the authors did not explore any of the problems that can arise when "silenced minorities" voice their concerns in law schools. See Scassa, supra note 4.

36 Some of these feminist methodologies may be used in critical pedagogies ("perpetual questioning”, for example). As well, the focus on "artificial dichotomies" and "rejection of abstraction" may be seen as curricular issues as well as pedagogical ones.

37 See, for example, M Belenky, B Clinchy, N Goldberger, \& J Tarule, Women's Ways of Knowing: The Development of Self, Voice and Mind (New York: Basic Books Inc., 1986); and Gilligan, supra note 32. See also N Lyons, Dilemmas of Knowing: Ethical and Epistemological Dimensions of Teachers’ Work and Development (1990) 60 Harv Educ Rev 159; and C Menkel-Meadow, Women as Law Teachers: Toward the Feminization of Legal Education, in Essays on the Application of a Humanistic Perspective to Law Teaching (1981) 16. "Feminists in other disciplines have also critiqued epistemological issues. For example, see S Harding ed, Feminism and Methodology: Social Science Issues (Bloomington, Milton Keynes (Buckinghamshire): Indiana University Press, 1987); S Harding The Science Question in Feminism (Ithaca: Cornell University Press, 1986); E Showalter, Feminist Criticism in the Wilderness (1981) Critical Inquiry 179; and A Kolodny, Dancing through the Minefield: Some Observations on the Theory, Practice, and Politics of a Feminist Literary Criticism (1980) 6 Feminist Stud 19. There is also some suggestion that (at least early on) these methodological approaches in the Women's Studies field were not always successful in achieving their defined objectives: see M Boxer, For and About Women: The Theory and Practice of Women's Studies in the United States (1982) Signs 661 , especially at 672-73.

38 For Canadian examples, see M O’Brien \& S McIntyre, Patriarchal Hegemony and Legal Education (1986) 2 Can J Women \& L 69; T Quandt, Learning Exclusion: A Feminist Critique of the Law School Experience (1993) 4 Educ \& LJ 279; S McIntyre, Promethea Unbound: A Feminist Perspective on Law in the University (1989) 38 U New Brunswick LJ 157; and J Abramcyzk, The Tyranny of the Majority: Liberalism in Legal Education (1992) 5 Can J Women \& L 442.

39 In the broader university context, see, for example, R Hall, \& B Sandler, The Classroom Climate: A Chilly One for Women. (Washington: Association of American Colleges Project on the Status and Education of Women, 1982); S Conway, \& AI Dagg, Sexism and Universities: The Myth of Academic Excellence: A Brief Presented to the Commission of Inquiry on Canadian University Education by the Caravan of University Feminists (Toronto: Unpublished brief, 1990). An interesting argument for feminists to continue working in academia (in spite of difficulties) is SM Gearhart, If the Mortarboard Fits ... Radical Feminism in Academia, in Bunch, \& Pollack eds, supra note 28. See also AC Scales, Surviving Legal De-Education: An Outsider's Guide (1990) 15 Vt L Rev 139.

40 See C Smart, Law's Truth/women's experience, in R Graycar ed, Dissenting Opinions: Feminist Explorations in Law and Society (Sydney: Alien and Unwin, 1990) 1; and C Smart, The Power of Law (New York: Routledge: 1989). See also M Thornton, Discord in the Legal Academy: The Case of the Feminist Scholar (1994) 3 Austl Feminist LJ 53.

41 C Littleton, Women's Experience and the Problem of Transition: Perspectives on Male Battering of Women [19891 U Chi Legal F 23, at 47-48. For a good example, see J Morgan, The Socratic Method: Silencing Cooperation (1989) 1 Legal Educ Rev 151.

42 See S McIntyre, The "Memo" and its Impact (1987-88) 2 Can J Women \& L 362; and D Majury, Collective Action on a Systemic Problem, in C Lambert ed, Toward a New Equality: The Status of Women in Canadian Universities (Ottawa: Social Science Federation of Canada, 1991) 13.

43 Thornton, supra note 7. See also M Le Brun \& R Johnstone, The Quiet (R)evolution: improving Student Learning in Law (Sydney: Law Book, 1994).

44 BH Davis, Teaching the Feminist Minority, in Bunch, \& Pollack eds, supra note 28, at 89. Her comments (at 95-96) about teaching strategies in a "mixed" context are especially interesting: "Recognizing [the needs of mixed groups of students] may enable us to understand the paradoxes of our own behaviour as teachers. My own teaching strategies, for example, have become more conservative even as my feminism has become more radical. This reflects the conservatism of my students and my belief that within a conservative institution only carefully constructed support will permit the transition to other modes ... What is effected by the process ... is awareness of the shaping power of language: that understanding of the crucial life experiences of women involves learning to 'think like' other women ...” For other illustrations, see K Harbeck ed, Coming Out of the Classroom Closet: Gay and Lesbian Students, Teachers and Curricula (New York: Harrington Park Press, 1992); B Balos, Learning to Teach Gender, Race, Class and Heterosexism: Challenge in the Classroom and Clinic (1992) 3 Hastings Women's LJ 161; and P McIntosh, White Privilege: Unpacking the Invisible Knapsack [1989] Peace \& Freedom 10.

45 This suggestion does not mean that strategies will be without negative consequences, some of which may not even be apparent. As has been suggested by Luke, \& Gore, supra note 22, at 195, the position of feminist law teachers as gendered subjects may result in contradictor outcomes: "The issues we contest, the various fronts on which we struggle, and the political strategies we use are often loaded with contradictory meanings and effects. If we act one way, it may have repercussions on another level; if we get outraged over one issue, we will make enemies in one camp but form alliances in another; if we speak and behave unbefitting the feminine academic image, we may lose the attention of those men whose attention we need in order to get our agenda on board. In short, in all that we do as women, we are always already marked as other."

46 SS Friedman, Authority in the Feminist Classroom: A Contradiction in Terms?, in Culley, \& Portuges, supra note 4, 203 at 206.

47 P Treichler, Teaching Feminist Theory, in C Nelson ed, Theory in the Classroom (Urbana: University of Illinois, 1986) 86; as quoted by S Heald, The Madwoman out of the Attic: Feminist Teaching at the Margins (1993) 22 Resources for Feminist Res 22

48 Heald, supra note 47, at 23.

49 SA Basow, Student Ratings of Professors are not Gender Blind (Unpublished, Lafayette College, 1994).

50 Id.

51 Id.

52 T Quandt, Learning Exclusion: A Feminist Critique of the Law School Experience (1993) 4 Educ \& LJ 279, 304. Commenting on the role of feminist law teachers in the context of power relationships in the law school, the student suggested that: "Generally, ... feminist professors had little power to make changes at the law school ... One reason was that some female professors had little job 
security, which forced them to 'play the game', while other professors were simply not taken seriously by students or professors as they struggled for change."

53 C Neely, Feminist Criticism in Motion, in P Treichler, C Kramarae, \& B Stafford eds, For Alma Mater: Theory and Practice in Feminist Scholarship (Urbana: University of Illinois Press, 1985) 82; as voted in Heald, supra note 47.

54 For an account of the dynamics of classroom interactions among male and female students, see CG Krupnick, Women and Men in the Classroom: Inequality and its Remedies (On Teaching and Learning, the Journal of the Harvard-Danforth Centre: May 1985). The research indicated that male students were more likely to dominate classrooms where they were in the majority and the instructor was also male, but that female students spoke almost three times longer with female instructors. The author also suggested that teachers who wait for volunteers in classroom discussions, rather than calling on students directly, exacerbate the division of the classroom into "participants" and "non-participants", a factor which may contribute to women's "less than equal experience of coeducation”. Id at 22.

55 For an account of power relations in the university, see H Bannerji et al, Unsettling Relations: The University as a Site of Feminist Struggle (Toronto: Women's Press, 1991). See also N Baym, The Feminist Teacher of Literature: Feminist or Teacher?, in S Gabriel, \& T Smithson eds, Gender in the Classroom: Power and Pedagogy (Urbana: University of Illinois Press, 1990).

56 F Maher, Classroom Pedagogy and the New Scholarship on Women, in Culley, \& Portuges eds, supra note 4,29 at 47. Not everyone would agree, of course, about the extent to which we may be able to democratise the classroom.

57 U Narayan, Working Together Across Difference: Some Considerations on Emotions and Political Practice (1988) 3 Hypatia 31, at 35 .

58 Id at 36

59 Id.

60 Id at 47. Narayan has usefully identified some ways that the advantaged may fail in their efforts to communicate with those who are disadvantaged, by violating the latter's sense of self-identity, self-worth or self-respect. Her suggestions may be useful in relation to gender and also in other situations of power differences in a classroom. For example, she suggests that it is not appropriate for an advantaged person to deny the validity of the disadvantaged person's understanding of the issue or response to it. See id, 41-46.

61 E Ellsworth, Why Doesn't This Feel Empowering? Working Through the Repressive Myths of Critical Pedagogy (1989) 59 Harv Educ Rev 297, at 324.

62 U Narayan, supra note 57, explored the potential for such communication in the context of heterogeneous groups working to together, and identified (at 39) a number of ways that "insiders" and "outsiders" (in terms of power relationships) may unintentionally fail to communicate effectively, problems which may also occur in the classroom: “An outsider who has not experienced an oppression first-hand and has learned about it second-hand, is more likely to understand the general and commonplace ways in which the oppression is manifested. For instance, if a professor uses openly racist or sexist examples or is openly hostile to minority or female students, sympathetic white male students may be able to spot his attitudes quite as well as the victim. But if his attitudes are expressed more covertly, through dismissing their queries, not taking their contributions seriously, under-valuing their work, lack of cordiality, etc., outsiders may fail to see what is going on.”

63 U Franklin, Letter to a Graduate Student (1993) 13 Can Women's Stud 12, at 15. See also C Overall, Women and Men in Education (Sixth Annual MacClement Lecture for Excellence in Education, Queen’s University: 1991). 